\title{
Nutrient uptake rate for yard long bean
}

\author{
André Luiz B da Cunha ${ }^{1 \mathbb{D}}$; Francisco Célio M Chaves ${ }^{2 \mathbb{D}}$; Cristiaini Kano ${ }^{3 \mathbb{D}}$; Ítalo G Braga ${ }^{1 \mathbb{D}}$; Marcelo \\ R de Oliveira ${ }^{2 \mathbb{D}}$
}

${ }^{1}$ Universidade Federal do Amazonas (UFAM), Manaus-AM, Brasil; andre_am10@hotmail.com; italo.k15@gmail.com; ${ }^{2}$ Embrapa Amazônia Ocidental, Manaus-AM, Brasil; celio.chaves@embrapa.br; marcelo.roseo@embrapa.br; ${ }^{3}$ Embrapa Territorial, Campinas-SP, Brasil; cristiaini. kano@embrapa.br

\begin{abstract}
Knowing about the nutrient uptake during plant cycle is essential for nutrient management decisions. We evaluated dry matter accumulation and nutrient demand, and it to determine the uptake curves, the ideal phase for management, and element extraction order for yard long beans. The experiment was carried out in a greenhouse. The experimental design was completely randomized, with eight collection periods, at 10, 20,30,40,50, 60,70 and 80 days after emergence (DAE), and four replicates. For each period, destructive sampling was performed and the sample's dry matter content was determined, so that it could be used to estimate macroand micronutrient contents. When significant, nonlinear models were adjusted to explain dry matter accumulation and nutrient uptake. The sigmoidal equation was the model which best depicted the growth curve for yard long bean, which reached a maximum biomass accumulation of $177.5 \mathrm{~g} \mathrm{plant}^{-1}$ at 80 DAE. The crop's most demanding phase in terms of nutritional requirements is from 20 to 45 DAE, which is the ideal phase for nutrient management. The element extraction order at the end of the plant's cycle was $\mathrm{K}>\mathrm{Ca}=\mathrm{N}>\mathrm{S}=\mathrm{P}>\mathrm{Mg}$ (macronutrients) with values of 2,668.3 mg plant ${ }^{-1}, 2,331.1 \mathrm{mg} \mathrm{plant}^{-1}$, 2,279.2 $\mathrm{mg} \mathrm{plant}^{-1}, 507.5 \mathrm{mg} \mathrm{plant}^{-1}, 496.3 \mathrm{mg} \mathrm{plant}^{-1}$ and $213.2 \mathrm{mg}$ plant $^{-1}$, and $\mathrm{Fe}>\mathrm{B}>\mathrm{Zn}>\mathrm{Mn}>\mathrm{Cu}$ (micronutrients), with $10,933.1 \mu \mathrm{g}$ plant $^{-1}, 6,310.8 \mu \mathrm{g}$ plant $^{-1}, 4,746.8 \mu \mathrm{g} \mathrm{plant}^{-1}, 2,854.1 \mu \mathrm{g}$ plant $^{-1}$ and $717.1 \mu \mathrm{g}$ plant ${ }^{-1}$, respectively.
\end{abstract}

Keywords: Vigna unguiculata susbp. sesquipedalis, macronutrient and micronutrient accumulation.

\section{RESUMO}

Taxa de acúmulo de nutrientes em feijão de metro

A determinação do acúmulo de nutrientes durante o ciclo vegetativo é essencial para estabelecer o manejo nutricional. Objetivou-se avaliar o acúmulo de matéria seca e a exigência nutricional, estabelecendo as curvas de absorção, a época ideal de manejo e a ordem de extração dos elementos. O experimento foi conduzido em casa de vegetação com delineamento experimental inteiramente casualizado com oito períodos de coleta aos 10, 20, 30, 40, 50, 60, 70 e 80 dias após a emergência (DAE), com quatro repetições. Em cada período, ocorreu uma coleta de forma destrutiva, para determinar a matéria seca e, assim, estimar o conteúdo de macro e micronutrientes. Foram ajustados, quando significativos, modelos não lineares para explicar o acúmulo de matéria seca e absorção de nutrientes. A equação sigmoidal foi o modelo que melhor representou a curva de crescimento das plantas de feijão-de-metro com acúmulo máximo de biomassa aos 80 DAE de 177,5 g planta $^{-1}$. A fase de maior exigência nutricional da cultura é no período de 20 a 45 DAE (início das fases de florescimento e frutificação), onde deve ser realizado o manejo nutricional. A ordem decrescente da extração total de macronutrientes pela planta no final do ciclo foi de $\mathrm{K}>\mathrm{Ca}=\mathrm{N}>\mathrm{S}=\mathrm{P}>\mathrm{Mg}$ com respectivos valores de 2.668,3 $\mathrm{mg} \mathrm{planta}^{-1}$, 2.331,1 mg planta ${ }^{-1}, 2.279,2 \mathrm{mg}$ planta $^{-1}, 507,5 \mathrm{mg} \mathrm{planta}^{-1}, 496,3 \mathrm{mg}$ planta $^{-1}$ e 213,2 mg planta $^{-1}$, e de micronutrientes $\mathrm{Fe}>\mathrm{B}>\mathrm{Mn}>\mathrm{Zn}>\mathrm{Cu}$, com 10.933,1 $\mu$ g planta $^{-1}, 6.310,8 \mu$ g lanta $^{-1}, 4.746,8 \mu$ g planta $^{-1}$, $2.854,1 \mu$ g planta $^{-1}$ e $717,1 \mu$ g planta $^{-1}$, respectivamente.

Palavras-chave: Vigna unguiculata susbp. sesquipedalis, acúmulo de macronutrientes e micronutrientes.

\section{Received on November 13, 2019; accepted on March 13, 2020}

$\mathrm{T}$ he yard long bean (Vigna unguiculata subsp. sesquipedalis) is a species of the Fabaceae family and produces pods which are strongly appreciated in the North region of Brazil (Silva et al., 2012). In the state of Amazonas, it plays an important role in family farming, to make crops more diverse and as a supplemental income.

The crop's nutritional aspect is also prominent. It is a cheap protein source (the seeds contain up to $28 \%$ protein) (Resmi \& Gopalakrishnan, 2004), and is also an alternative to snap beans (Phaseolus vulgaris) in this region, due to the occurrence of phytosanitary problems that limit the productivity of Phaseolus crops (Kano et al., 2018).

Obtaining high-quality pods depends directly on the crop's management practices. This is mainly due to the need for knowing the physiological variables involved in biomass accumulation (São José et al., 2014), and in turn, the nutritional requirement during the development phases (Almeida et al., 2012 ), as well as other factors.

One of the steps necessary to define the nutritional management of a crop is to carry out studies on the nutrient uptake rate (Haag et al., 1967). Nutrient uptake rate is expressed in the form of response curves, and depends on 
development period, the amount of nutrients needed for production, the time of highest demand for each nutrient, and the organ in which each nutrient is found in greater quantity (Marschner, 2012).

For yard long beans, the uptake rate is essential because it may define how much of the nutrients may be exported during the harvest period (Zobiole et al., 2010). The reproductive period, which precedes the harvest, is for most species a phase of greater demand for certain mineral elements, which can be essential for the formation of the pod (fruit vegetable), and must be qualitatively and quantitatively known.

According to Fageria et al. (2004), quantitative accumulation may be used as a parameter for nutrient removal from the soil in future fertilization recommendation systems. Furthermore, it defines the ideal time to apply fertilizers and to rationalize the use of inputs (Pinho et al., 2009).

Therefore, our objective in this work was to evaluate the growth of yard long beans using dry matter accumulation and nutritional requirements, and determine the uptake curves for $\mathrm{N}, \mathrm{P}$, $\mathrm{K}, \mathrm{Ca}, \mathrm{Mg}, \mathrm{S}, \mathrm{B}, \mathrm{Fe}, \mathrm{Cu}, \mathrm{Mn}$ and $\mathrm{Zn}$, as well as the ideal time for nutritional management and the order of extraction of these elements.

\section{MATERIAL AND METHODS}

The experiment was carried out in a greenhouse within Embrapa Amazônia Ocidental's Medicinal Plants and Vegetables sector $\left(03^{\circ} 06^{\prime} 23^{\prime \prime} \mathrm{S}\right.$, $60^{\circ} 01^{\prime} 35^{\prime \prime} \mathrm{W}$ ), in Manaus-AM, from July to September 2018.

The plants were grown in 3-L, black polyethylene plastic pots with 17.5 $\mathrm{cm}$ upper diameters, $15.0 \mathrm{~cm}$ lower diameters and $15.0 \mathrm{~cm}$ height, and with no holes in their lower part. An irrigation valve was adapted on the side of the pot, $1 \mathrm{~cm}$ distant from the base. A $10 \mathrm{x}$ $10 \mathrm{~cm}$ "D28" sponge was placed on the inside, by the faucet, in order to retain the substrate and facilitate the washing processes (Figure 1).

White quartz sand was used as substrate and sieved through 4-mm and $1-\mathrm{mm}$ mesh sieves, in that order. The sand was then washed under running water until the drained water was clear. Then, the sand was purified in a $0.5-\mathrm{M}$ $\mathrm{HCl}$ solution for six hours, washed again three times under tap water, and finally two more times using deionized water. The sand was placed to dry in a solar dryer, and $3 \mathrm{~kg}$ of dry sand were added to each pot.

We used yard long bean seeds of the cowpea cultivar Metro produced by Hortivale $^{\circledast}$ company and harvested in 2016. The spacing was $0.8 \mathrm{~m}$ between plants and $1.0 \mathrm{~m}$ between lines. Five seeds were sown in each pot. Ten days after sowing, four plants were thinned, and only the most vigorous remained.

We used the Hoagland \& Arnon's modified nutrient solution with the following reagent concentrations to prepare the stock solution: Macronutrientes $\left(\mathrm{g} \mathrm{L}^{-1}\right)=115.0 \mathrm{~g}$ of $\left(\mathrm{NH}_{4}\right) \mathrm{H}_{2} \mathrm{PO} ; 236.16 \mathrm{~g}$ of $\mathrm{Ca}\left(\mathrm{NO}_{3}\right)_{2} \cdot 4 \mathrm{H}_{2} \mathrm{O}$; $247.47 \mathrm{~g}$ of MgSO $4.7 \mathrm{H}_{2} \mathrm{O} ; 74.56 \mathrm{~g}$ of $\mathrm{KCl} ; 87.1 \mathrm{~g}$ of $\mathrm{K}_{2} \mathrm{SO}_{4}^{2} ; 80.04 \mathrm{~g}$ of $\mathrm{NH}_{4} \mathrm{NO}_{3} ; 256.43 \mathrm{~g}$ of $\mathrm{Mg}\left(\mathrm{NO}_{3}\right)_{2} \cdot 6 \mathrm{H}_{2} \mathrm{O}$.

For the micronutrients, only one stock solution was produced (except for iron) with the following concentrations $=2.86 \mathrm{mg}$ of $\mathrm{H}_{3} \mathrm{BO}_{3} ; 1.81 \mathrm{mg}$ of $\mathrm{MnCl}_{2} .4 \mathrm{H}_{2} \mathrm{O} ; 0.22 \mathrm{mg}$ of $\mathrm{ZnSO}_{4} .7 \mathrm{H}_{2} \mathrm{O}$; $0.03 \mathrm{mg}$ of $\mathrm{CuCl}_{2} ; 0.018 \mathrm{mg}$ of $\left(\mathrm{NH}_{4}\right)_{6} \mathrm{Mo}_{7} \mathrm{O}_{24} \cdot 4 \mathrm{H}_{2} \mathrm{O} ;$ all micronutrients were diluted in $1 \mathrm{~L}$ deionized water. FeEDTA was the source of iron, with the following concentrations $=33.2 \mathrm{~g} \mathrm{~L}^{-1}$ of $\mathrm{Na}_{2}$-EDTA; $100 \mathrm{~mL} \mathrm{~L}^{-1}$ of $\mathrm{NaOH}$ (1 $\mathrm{M}) ; 4 \mathrm{~mL} \mathrm{~L}^{-1}$ of $\mathrm{HCl}(1 \mathrm{M}) 24.9 \mathrm{~g} \mathrm{~L}^{-1}$ of $\mathrm{FeSO}_{4} \cdot 7 \mathrm{H}_{2} \mathrm{O}$.

The nutrient solution was used according to the development of the plants, from five days after emergence (DAE) onwards. A solution with $25 \%$ ionic strength was applied to the plant in the fifth and eighth DAE. In the $10^{\text {th }}$ DAE the ionic strength was changed to $50 \%$, and so it remained until the $20^{\text {th }}$ DAE, after which it was increased to $80 \%$.

The nutrient solution was applied every two days, and deionized water was added in the intervals between these applications. The solutions' $\mathrm{pH}$ and electrical conductivity were monitored every two days, and kept in the 5.8-6.0 and 1.8-2.0 dS m $\mathrm{dr}^{-1}$ ranges respectively.
The solutions were changed weekly, and the substrate was washed periodically every fifteen days using deionized water, in order to avoid damages caused by toxicity.

The plants were vertically tutored after reaching $2 \mathrm{~m}$ height from the ground up until the end of the experiment, due to their climbing growth habit. During the growing period there was need for chemical control using Deltamethrin and Abamectin to control aphids (Aphis gossypii) and leafminers (Liriomyza spp.) respectively.

The experiment was performed under a completely randomized design with 8 evaluation periods, at 10,20 , $30,40,50,60,70$ and $80 \mathrm{DAE}$, with four replicates composed of two plants each. Only at 10 DAE ten plants were collected for each replicate, due to their decreased development.

For each collection period, the plants were destructively harvested and divided into: Roots (removed from the base of the root collar downwards); Stem (from the root collar to the upper end, including all branches); Leaves [(leaf blade and petioles) all leaves were collected, including the senescent ones detached from the plants between the evaluation periods, and were stored in a Kraft paper bag]; Reproductive parts [include flowers at all development stages and fruits, both before ripening (fit for commercialization or not) and ripe]. The pods already fit for commercialization were harvested every 2 days and put to dry in a shed, on benches protected from the sun, for seven days.

The different parts were washed with deionized water. After excess water removal, they were packed in paper bags and taken to dry in an oven with forced air circulation at $65^{\circ} \mathrm{C}$ until reaching constant mass (Malavolta et al., 1997). Using an analytical scale, we weighed the dry matter contents for all different parts (roots, stem, leaves, and reproductive parts), and calculated the total biomass.

Dry samples of each part (roots, stem, leaves and reproductive parts) were ground using a Wiley mill, and the total levels of $\mathrm{N}, \mathrm{P}, \mathrm{K}, \mathrm{Ca}, \mathrm{Mg}$ and $\mathrm{S}$, in 
$\mathrm{g} \mathrm{kg}^{-1}$, and $\mathrm{B}, \mathrm{Cu}, \mathrm{Fe}, \mathrm{Mn}$ and $\mathrm{Zn}$, in $\mathrm{mg}$ $\mathrm{kg}^{-1}$, were determined using the method developed by Silva (2009). Biomass accumulation was determined for each nutrient by multiplying each element's content by the dry-matter value for each part, and the total biomass accumulation was calculated by the sum of all parts.

The data were subjected to analysis of variance, with an interaction of eight periods $\mathrm{x}$ four parts of the plant, with four replicates. The "part of the plant $x$ nutrient" interaction was also considered as a source of variation, $4 \times 6$ for macronutrients and $4 \times 5$ for micronutrients, in percentage, to determine the uptake rate.

To adjust the equations, since there is functional correlation between days after emergence $(x)$ and the accumulation response variable (y), non-linear regression models were tested: $\mathrm{G}$ (Gaussian model $)=\left\{\mathrm{a}^{*} \exp [-\right.$ $\left.\left.0.5^{*}(\mathrm{x}-\mathrm{x} 0) / \mathrm{b}\right]^{2}\right\} ; \mathrm{S}$ (Sigmoidal model $)=$ $\mathrm{a} /\{1+\exp [-(\mathrm{x}-\mathrm{x} 0) / \mathrm{b}]\} ;$ L (Lorentzian model $)=\mathrm{a} /[1+(\mathrm{x}-\mathrm{x} 0) / \mathrm{b}]^{2}$.

Each model chosen for explaining the behavior of dry matter accumulation, total nutrient accumulation and their divisions used the following criteria: higher determination coefficient, significance of the regression coefficients up to $5 \%$ probability by the $\mathrm{F}$ test, and biological significance of the model.

Based on the results, we estimated the parameters of the models adjusted in each equation, which determined the point of maximum accumulation of the nutrient, in mg plant $^{-1}$ (a), the DAE when the maximum accumulation rate was reached $(\mathrm{x} 0)$ and the amplitude, in DAE, between the turning point and the maximum point (b).

Therefore, once the parameters were estimated, we could determine the PI (turning point) value as the difference between $\mathrm{x} 0$ and $\mathrm{b}(\mathrm{x} 0-\mathrm{b})$. PI is an important parameter, because it defines, in DAE, the time when the accumulation rate changes from positive to negative.

\section{RESULTS AND DISCUSSION}

\section{Dry matter accumulation}

Total dry matter accumulation was significant, and its behavior was adjusted to the sigmoidal model (Figure 2). According to Cairo et al. (2008), this model depicts the classic plant growth process in three distinct phases.

Phase 1, from germination up to $20 \mathrm{DAE}$, is considered a stage of little dry matter accumulation, due to the low amount of leaves and roots and the absence of reproductive parts.

Phase 2, which ranged from 20 DAE to $70 \mathrm{DAE}$ in this experiment, is characterized by intense dry matter accumulation. This period also coincides with the increase in dry matter content in leaves (photosynthesis) and roots (nutrient uptake), therefore there is greater accumulation of organic compounds formed by $\mathrm{CO}_{2}$ incorporation (Cairo et al., 2008).

After $70 \mathrm{DAE}$, in the third phase (phase 3), there is less accumulation of total dry matter, because there is a balance between tissue formation (production) and the senescence (death) and abscission processes (Benincasa, 2003). The plant's growth curve reached maximum total dry biomass accumulation of $177.5 \mathrm{~g} \mathrm{plant}^{-1}$ at 80 DAE.

Similar growth behavior in terms of curve fit was determined by Brito et al. (2009) for cowpea (Vigna unguiculata), and also in terms of sigmoidal fit: from the reproductive phase onwards there was an increase in total dry matter content, which reached its maximum point at 78 days after sowing.

For yard long beans grown under different irrigation management practices, Silva et al. (2012) obtained results ranging from 120 to $260 \mathrm{~g}$ plant $^{-1}$ for total dry matter accumulation in the aerial parts at 82 DAE. In this experiment, the average rate for the yard long beans was of $177.5 \mathrm{~g} \mathrm{plant}^{-1}$.

The dry matter content of leaves, stem and roots reached their maximum accumulation point at 80,71 and 70 DAE respectively. Studying common beans, Zucareli et al. (2010) and Santos et al. (2015) also obtained similar results for these variables in the 55 to $70 \mathrm{DAE}$ range.

For the stem and roots we observed that the decrease in dry matter content occurred more intensely at the end of the cycle, due to the plants' senescence process, during which there is low remobilization of photoassimilates in comparison to other stages of the production process. For the leaves, which are considered source organs, the decrease in total dry matter content is mainly due to the reproductive season, and is intensified by senescence and abscission (Santos et al., 2015).

In the plants' reproductive parts, dry matter production started at $30 \mathrm{DAE}$, when the first flowers appeared, also with sigmoidal fit. The maximum value, $122.1 \mathrm{~g} \mathrm{plant}^{-1}$, was reached at $80 \mathrm{DAE}$.

Nitrogen, phosphorus and potassium accumulation

The total accumulation for $\mathrm{N}, \mathrm{P}$ and $\mathrm{K}$ is shown in Figure 3, and the adjustments made to the equations are shown in Table 1. Accumulation occurred slowly for these three nutrients up until 20 DAE (Figures 3A, 3B and 3C respectively), due to the smaller increase in total dry matter content caused by the yet poorly formed root system and to the smaller amount of leaves, which produced a lower growth rate.

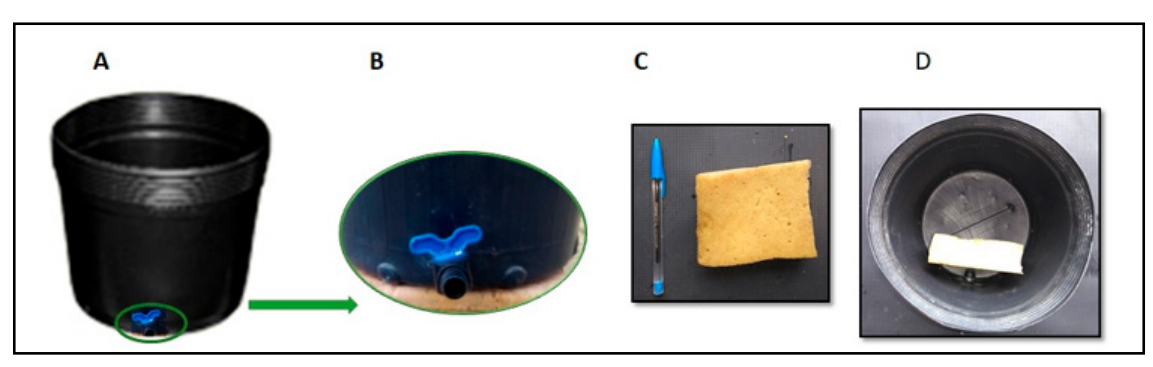

Figure 1. Diagram of the structure of the pot used for growing the yard long bean plants. $\mathrm{A}=$ frontal view of the pot, showing the drain valve; $\mathrm{B}=$ zoom of the water drain valve; $\mathrm{C}=$ D-28 sponge used on the inside of the pot, to retain the substrate; $\mathrm{D}=$ assembly of the drain valve and sponge before substrate addition. Manaus, UFAM, 2018. 


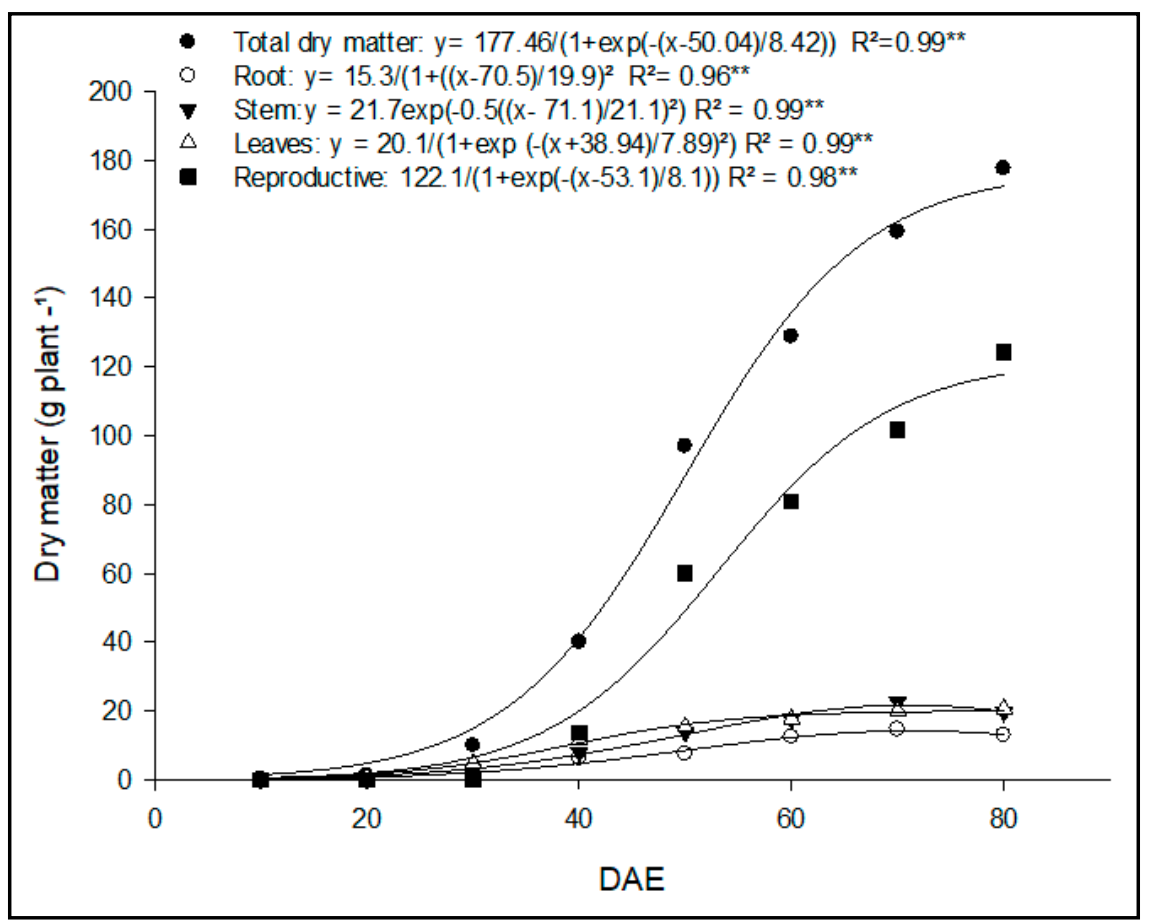

Figure 2. Total dry matter $(\bullet)$, root $(0)$, stem $(\boldsymbol{\nabla})$, leaves $(\Delta)$ and reproductive parts $(\boldsymbol{\square})$ of the yard long bean plants grown in pots with nutrient solution. $\mathrm{DAE}=$ days after emergence. Manaus, UFAM, 2018.

Similar results were obtained for common beans (Phaseolus vulgaris) by Pegoraro et al. (2014). During this period, the leaf allocated up to $69 \%$ of the $\mathrm{N}$ contained in the plant. After this phase the behavior of the accumulation curve was adjusted to the sigmoidal model, that is, the point of maximum accumulation occurs only at the end of the cycle.

According to Table 1, the point at which the total accumulation rate shows the greatest increase was around 37 to 40 DAE for N, P and K. This period is called a turning point (PI), when the daily accumulation rate starts to decrease, even though the gains are positive (Zobiole et al., 2010). Fertilizers must be applied by top dressing before this period.

According to the equation, $\mathrm{N}$ and $\mathrm{K}$ reached at their maximum point a total accumulation of 2,279.2 and 2,668.3 mg plant ${ }^{-1}$ respectively (Figures $3 \mathrm{~A}$ and 3C), while for $P$ the result obtained was 496.3 mg plant $^{-1}$ (Figure 3B). Up until $40 \mathrm{DAE}$, the leaf was the main organ of allocation for $\mathrm{N}$ and $\mathrm{K}$, with about $38 \%$ and $32 \%$ of these elements' total amounts respectively.
Growing jack beans (Canavalia ensiformes), Teixeira et al. (2010) also detected the maximum point for $\mathrm{N}$ and $\mathrm{K}$ at the end of the cycle, at 60 and 58 DAE respectively. For phosphorus, the highest allocation was already in the reproductive part $(40 \%$ of the total) at 40 DAE. According to Maathuis (2009), phosphorus is required in all of the plant's stages. However a great part is required for the formation of reproductive structures and for grain filling.

Nevertheless, in the full production phase (50 DAE), nutrient accumulation was greater in the reproductive organs (REP), which include flowers, pods and seeds, as shown in Figures 3A, $3 \mathrm{~B}$ and $3 \mathrm{C}$. After the beginning of the reproductive phase at $30 \mathrm{DAE}$, we observed a redistribution of the three nutrients, and their main source organ was the leaf.

The period that comprises the point of greatest demand by the plant coincides with the beginning of the fruiting stage. At this phase, the partition of photoassimilates and mineral nutrients, which are stored in the leaves, occurs more intensely, and it is when the reproductive phase predominates over the vegetative phase, to form pods and seeds (Marschner, 2012).

At the end of the experiment (80 DAE), the reproductive part, adjusted to the sigmoidal model, reached highest allocation with maximum accumulation of $1,607.7 \mathrm{mg}_{\text {plant }}{ }^{-1}(\mathrm{~N}), 411.0 \mathrm{mg}$ plant $^{-1}(\mathrm{P})$ and $2,054.9 \mathrm{mg}$ plant $^{-1}$ (K), $75 \%, 80 \%$ and $78 \%$ of the total accumulation respectively.

For all three nutrients, in the full fruiting period, from 50 DAE until the end of the experiment, the leaf was the organ that showed the highest reduction percentages for total accumulation, and varied on average from $32 \%$ at $50 \mathrm{DAE}$ to up to $4 \%$ at $80 \mathrm{DAE}$, which shows its importance for the redistribution of nutrients and assimilates.

\section{Calcium, magnesium and sulfur accumulation}

For Ca (Figure 3D), Mg (Figure $3 \mathrm{E}$ ) and $\mathrm{S}$ (Figure 3F) the behavior of the total accumulation curve showed better fit to the sigmoidal model (Table 1), that is, the point of maximum total accumulation occurred at 80 DAE. However, the turning point of the curve occurs before the maximum point for $\mathrm{Ca}$, at $47 \mathrm{DAE}$, for $\mathrm{Mg}$, at $38 \mathrm{DAE}$, and for $\mathrm{S}$, at 42 DAE. (Table 1).

For N, P and K, there was strong accumulation starting at 20 DAE. The total amount accumulated at the maximum point was $2,331.1 \mathrm{mg}$ plant $^{-1}$ (Ca), 213.2 mg plant $^{-1}(\mathrm{Mg})$, and 507.5 mg plant ${ }^{-1}(\mathrm{~S})$.

Ca (Figure 3D) was the only macronutrient for which, throughout the whole cycle, the leaf was the main allocation organ. Even with an increased demand for it during the reproductive phase, its content in the leaves was still high, and ranged from $74 \%$ to $85 \%$. This element is almost completely immobile inside the phloem, and when deposited in the leaves it may accumulate in large quantities. However, in many species the transpiration flow may guarantee significant amounts of calcium in other parts of the plants (Kerton et al., 2009).

In this organ, $\mathrm{Ca}$ accumulation reached its maximum point at $1,970.6$ mg plant ${ }^{-1}$, that is, a content of up to 59 $\mathrm{g} \mathrm{kg}^{-1}$. Under field cropping conditions, 
Kano et al. (2018) detected an average $\mathrm{Ca}$ content of $20.6 \mathrm{~g} \mathrm{~kg}^{-1}$ for yard long beans in the flowering phase.
The highest $\mathrm{Ca}$ accumulation in the leaves is mainly due to the fact that it participates in several functions within the plant, both structurally and as a messenger, and it is also an important component of the cell wall (Maathuis,

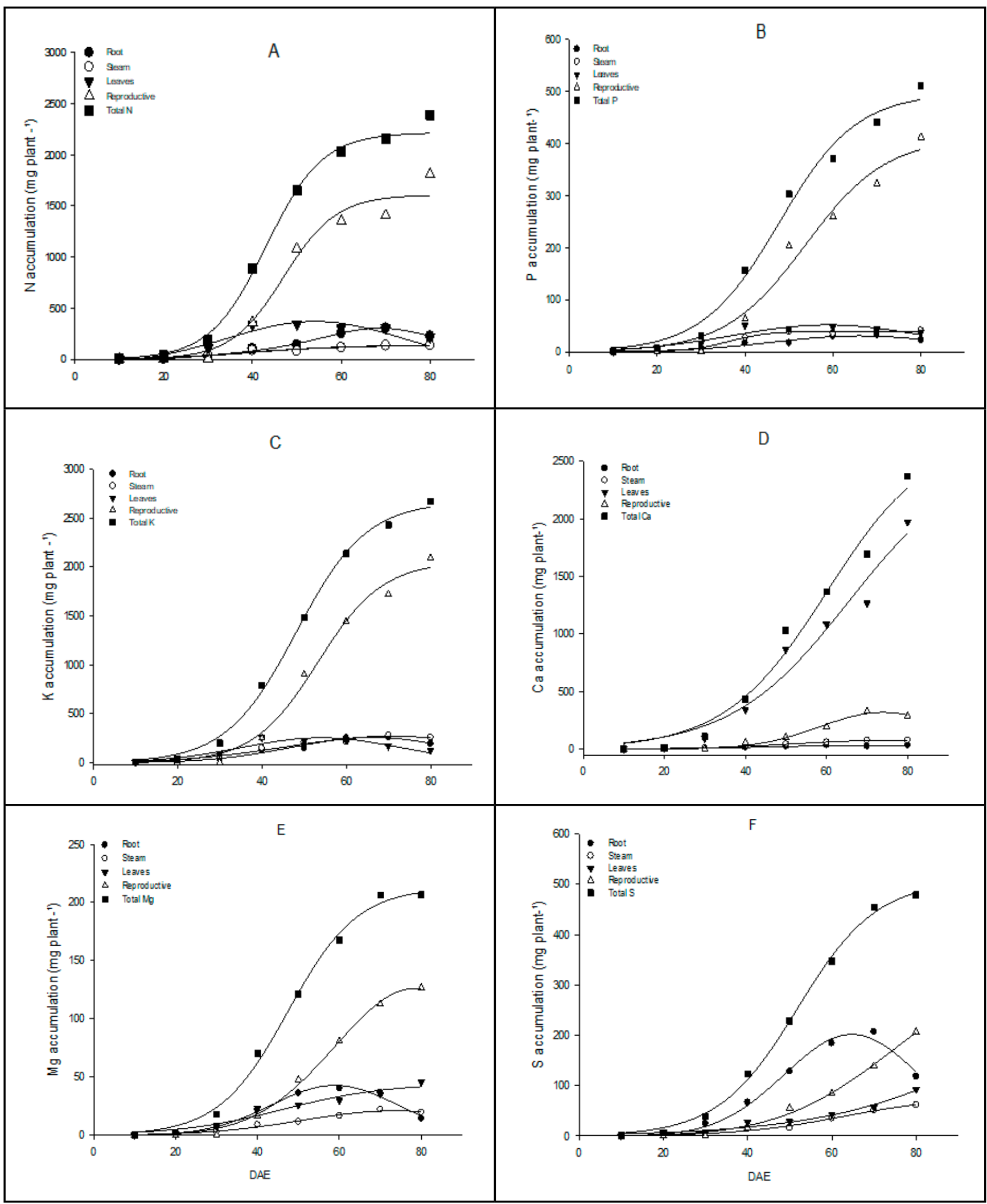

Figure 3. Macronutrient accumulation. $\mathrm{N}=\operatorname{nitrogen}(\mathrm{A}) ; \mathrm{P}=$ phosphorus $(\mathrm{B}) ; \mathrm{K}=\operatorname{potassium}(\mathrm{C}) ; \mathrm{Ca}=\operatorname{calcium}(\mathrm{D}) ; \mathrm{Mg}=\operatorname{magnesium}(\mathrm{E}) ; \mathrm{S}=$ sulfur $(\mathrm{F})$, during the cycle of yard long beans grown in pots containing nutrient solution. DAE= days after emergence. Manaus, UFAM, 2018. 
2009).

In the cytosol, calcium is central for intracellular signaling, while in the vacuole, the accumulation of calcium salts may offer significant contribution to osmotic homeostasis (Kerton et al.,
2009). Calcium is involved in many plant signaling processes, mainly in biotic and abiotic stress situations

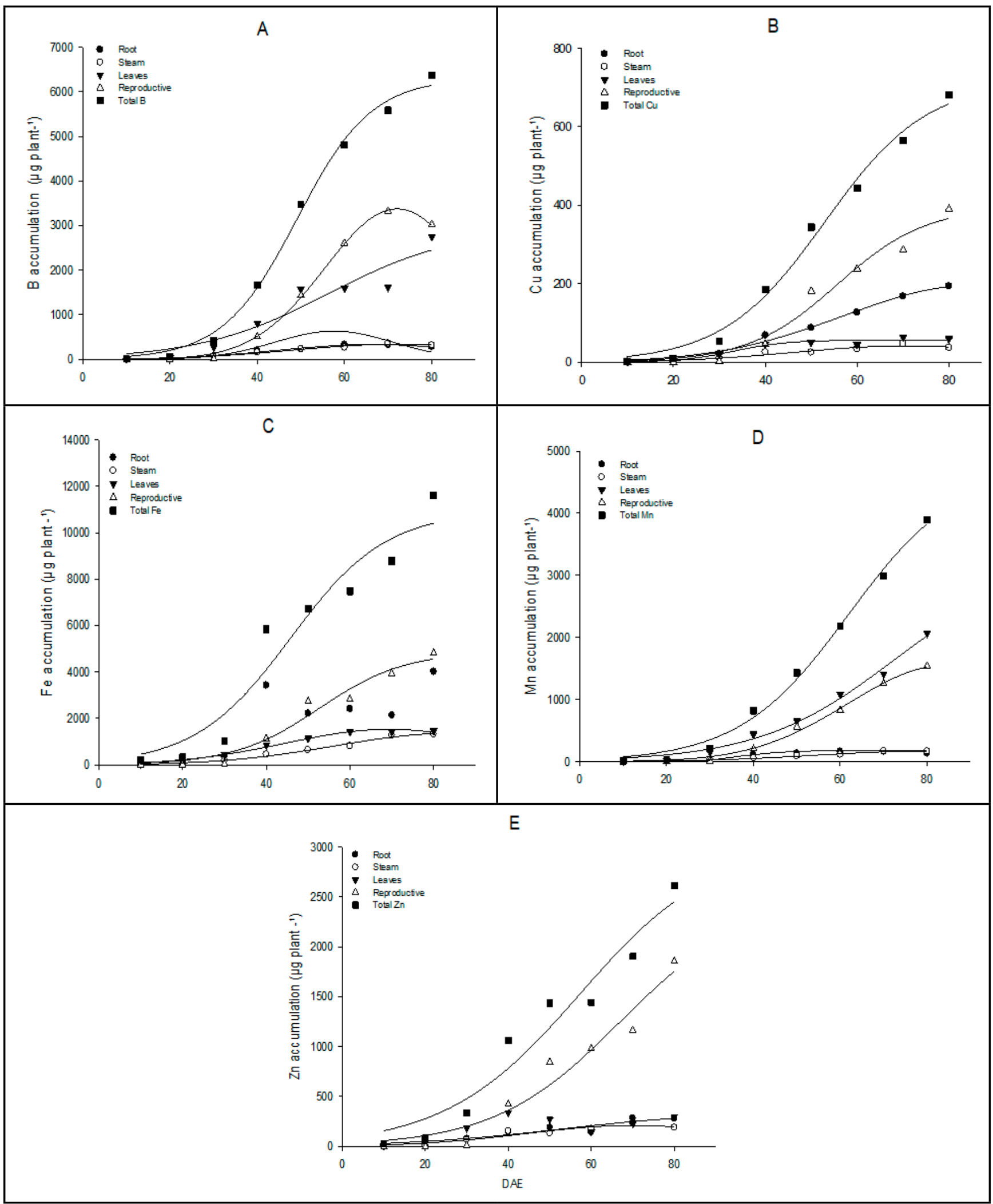

Figure 4. Micronutrient accumulation. $\mathrm{B}=$ boron $(\mathrm{A}) ; \mathrm{Cu}=$ copper $(\mathrm{B}) ; \mathrm{Fe}=$ iron $(\mathrm{C}) ; \mathrm{Mn}=$ manganese $(\mathrm{D})$; $\mathrm{Zn}=\mathrm{zinc}(\mathrm{E})$, during the cycle of yard long beans grown in pots containing nutrient solution. DAE= days after emergence. Manaus, UFAM, 2018. 
Table 1. Parameter estimates of the models adjusted for nitrogen, phosphorus, potassium, calcium, magnesium and sulfur accumulation over time and their respective turning point (PI) values. Manaus, UFAM, 2018.

\begin{tabular}{|c|c|c|c|c|c|}
\hline \multirow{3}{*}{ Part of the plant } & \multicolumn{3}{|c|}{$\begin{array}{c}\text { Parameter estimates of the } \\
\text { adjusted models }\end{array}$} & \multirow{2}{*}{$\begin{array}{c}\text { PI } \\
(x 0-b)\end{array}$} & \multirow{3}{*}{$\mathbf{R}^{2}$} \\
\hline & $\mathbf{a}$ & x0 & $\mathbf{b}$ & & \\
\hline & $\begin{array}{c}(\mathbf{m g} \\
\left.\text { plant }^{-1}\right)\end{array}$ & \multicolumn{3}{|c|}{$\begin{array}{l}\text { (days after } \\
\text { emergence) }\end{array}$} & \\
\hline & \multicolumn{5}{|c|}{ Nitrogen } \\
\hline $\operatorname{Root}^{\mathrm{L**}}$ & 343.60 & 69 & 21 & 47 & 0.99 \\
\hline Stem $^{S^{* *}}$ & 137.00 & 41 & 10 & 31 & 0.95 \\
\hline Leaves $^{\mathrm{G}^{* *}}$ & 366.33 & 57 & 20 & 37 & 0.94 \\
\hline Reproductive parts ${ }^{\mathrm{S**}}$ & $1,607.70$ & 47 & 6 & 41 & 0.99 \\
\hline \multirow[t]{2}{*}{ Total $^{* * *}$} & $2,279.20$ & 44 & 7 & 37 & 0.99 \\
\hline & \multicolumn{5}{|c|}{ Phosphorus } \\
\hline $\operatorname{Root}^{\mathrm{G}^{* *}}$ & 30.5 & 66 & 20 & 46 & 0.96 \\
\hline Stem $^{\mathrm{S}^{* *}}$ & 39.4 & 36 & 5 & 31 & 0.99 \\
\hline Leaves $^{\mathrm{G}^{* *}}$ & 52.6 & 59 & 22 & 37 & 0.94 \\
\hline Reproductive parts ${ }^{\mathrm{S**}}$ & 411.0 & 54 & 9 & 45 & 0.99 \\
\hline \multirow[t]{2}{*}{ Total $^{\mathrm{S**}}$} & 496.3 & 48 & 9 & 39 & 0.99 \\
\hline & \multicolumn{5}{|c|}{ Potassium } \\
\hline $\operatorname{Root}^{\mathrm{G}^{* *}}$ & 257,4 & 66 & 19 & 47 & 0.97 \\
\hline Stem $^{\mathrm{G}^{* *}}$ & 270.9 & 71 & 25 & 46 & 0.96 \\
\hline Leaves $^{\mathrm{G}^{* *}}$ & 254.1 & 54 & 19 & 33 & 0.94 \\
\hline Reproductive parts ${ }^{\mathrm{S}^{* *}}$ & $2,054.9$ & 53 & 8 & 45 & 0.99 \\
\hline \multirow[t]{2}{*}{ Total $^{\text {** }}$} & $2,668.3$ & 48 & 8 & 40 & 0.99 \\
\hline & \multicolumn{5}{|c|}{ Calcium } \\
\hline $\operatorname{Root}^{\mathrm{G}^{* *}}$ & 31.8 & 71 & 23 & 48 & 0.91 \\
\hline Stem $^{\mathrm{G}^{* *}}$ & 77.3 & 76 & 23 & 53 & 0.99 \\
\hline Leaves $^{\mathrm{S}^{* *}}$ & $1,970.6$ & 65 & 14 & 51 & 0.98 \\
\hline Reproductive parts $\mathrm{G}^{\mathrm{G}^{* *}}$ & 318.4 & 74 & 16 & 58 & 0.98 \\
\hline \multirow[t]{2}{*}{ Total $^{* * *}$} & $2,331.1$ & 60 & 13 & 47 & 0.99 \\
\hline & \multicolumn{5}{|c|}{ Magnesium } \\
\hline $\operatorname{Root}^{\mathrm{G}^{* *}}$ & 42.8 & 59 & 15 & 44 & 0.98 \\
\hline Stem $^{\mathrm{G}^{* *}}$ & 20.9 & 74 & 23 & 51 & 0.98 \\
\hline Leaves $^{\mathrm{S**}}$ & 44.7 & 46 & 12 & 34 & 0.94 \\
\hline Reproductive parts $\mathrm{G}^{\mathrm{G}^{* *}}$ & 126.2 & 79 & 20 & 59 & 0.99 \\
\hline \multirow[t]{2}{*}{ Total $^{\mathrm{S**}}$} & 213.2 & 47 & 9 & 38 & 0.99 \\
\hline & \multicolumn{5}{|c|}{ Sulfur } \\
\hline $\operatorname{Root}^{G^{* *}}$ & 201.8 & 65 & 16 & 49 & 0.99 \\
\hline Stem $^{5 * *}$ & 76.8 & 62 & 12 & 50 & 0.99 \\
\hline Leaves ${ }^{* *}$ & 92.2 & 68 & 21 & 47 & 0.99 \\
\hline Reproductive parts ${ }^{S * *}$ & 307.1 & 72 & 12 & 60 & 0.99 \\
\hline Total $^{\mathrm{G}^{* *}}$ & 507.5 & 51 & 9 & 42 & 0.99 \\
\hline
\end{tabular}

$\mathrm{ns}=$ not significant $\mathrm{G}=$ gaussian model: $\mathrm{a}^{*} \exp \left\{-0.5^{*}[(\mathrm{x}-\mathrm{x} 0) / \mathrm{b}]^{2}\right\} ; \mathrm{S}=$ sigmoidal model: $\mathrm{a} /\{1+\exp [-(\mathrm{x}-\mathrm{x} 0) / \mathrm{b}]\} ; \mathrm{L}=$ lorentzian model: $\mathrm{a} /\left\{1+[(\mathrm{x}-\mathrm{x} 0) / \mathrm{b}]^{2}\right\}$.
(Kudla et al., 2010).

These values were higher than those obtained by Leal \& Prado (2008), of $27.1 \mathrm{~g} \mathrm{~kg}^{-1}$ at the time for leaf diagnosis, in common bean (Phaseolus vulgaris). Raij et al. (1996) suggest a range of 10$25 \mathrm{~g} \mathrm{~kg}^{-1}$, and Malavolta et al. (1997), a range of $20-25 \mathrm{~g} \mathrm{~kg}^{-1}$ both in the flowering period.

Regarding magnesium (Figure 3E), the accumulation was greater in leaves ( $45 \%$ to $48 \%$ ) and roots ( $36 \%$ to $44 \%$ ), during the growing period. After the beginning of the reproductive phase, there was a greater $\mathrm{Mg}$ remobilization to form the pods, and the gains ranged from $23 \%$ at 40 DAE to $61 \%$ at $80 \mathrm{DAE}$. At this stage, the organs that showed strongest reduction in magnesium accumulation were the roots, followed by the leaves, accounting for 7 and $22 \%$ of the total percentage respectively.

Unlike the remainder, S (Figure 3F) showed the highest percentage of allocation in the roots, at $10 \mathrm{DAE}$, and reached up to $77 \%$ at the end of the cycle (70 DAE). However, there was an intense redistribution of the $\mathrm{S}$ from the roots to the reproductive parts at 80 DAE, and a reduction of up to $47 \%$ in the total accumulation.

\section{Boron and copper accumulation}

The accumulation curves for $\mathrm{B}$ and $\mathrm{Cu}$ are shown in Figure 4, and their respective equation adjustments are shown in Table 2. Micronutrient accumulation occurred slowly up until $20 \mathrm{DAE}$, which is the beginning of the vegetative phase. This trend was also observed for the macronutrients.

For boron (Figure 4A), total accumulation in the plant was accelerated in the period from 20 to $70 \mathrm{DAE}$. The adjustment was made to the sigmoidal model, in which the maximum total accumulation was reached at $80 \mathrm{DAE}$, with $6,310.8 \mu \mathrm{g} \mathrm{plant}^{-1}$, and the turning point for total accumulation occurred at 40 DAE (Table 2).

Figure 4A shows that $B$ was allocated in larger quantities in the leaves up until the beginning of the reproductive phase (40 DAE), with $48 \%$ of the total accumulated. Boron is predominantly used in active growth organs, such as the apexes of the aerial parts and roots 
(Hansch \& Mendel, 2009).

When the reproductive phase begins, the demand for nutrients, including boron, increases, due to the formation of the reproductive structures (flowers and pods). There is an intense reduction in B accumulation in the leaves, stems and roots after $45 \mathrm{DAE}$, whereas in the reproductive parts the reduction occurs only at the end of the cycle (Figure 4A).

According to Chatterjee \& Bandyopadhyay (2017), in their reproductive phase legumes require greater amounts of boron, which plays a vital role in the development of reproductive organs. From the

Table 2. Parameter estimates of the models adjusted for boron, copper, iron, manganese and zinc accumulation over time and their respective turning point (PI) values. Manaus, UFAM, 2018.

\begin{tabular}{|c|c|c|c|c|c|}
\hline \multirow{3}{*}{ Part of the plant } & \multicolumn{3}{|c|}{$\begin{array}{c}\text { Parameter estimates of the } \\
\text { adjusted models }\end{array}$} & \multirow{2}{*}{$\begin{array}{c}\text { PI } \\
(x 0-b)\end{array}$} & \multirow{3}{*}{$\mathbf{R}^{2}$} \\
\hline & $\mathbf{A}$ & $\mathbf{x 0}$ & B & & \\
\hline & $\begin{array}{l}\mu \mathrm{g} \\
\text { plant }^{-1}\end{array}$ & \multicolumn{3}{|c|}{$\begin{array}{l}\text { (days after } \\
\text { emergence) }\end{array}$} & \\
\hline & \multicolumn{4}{|c|}{ Boron } & \\
\hline $\operatorname{Root}^{\mathrm{G}^{* *}}$ & 332.2 & 66 & 22 & 44 & 0.98 \\
\hline Stem $^{G^{* *}}$ & 338.9 & 72 & 24 & 48 & 0.98 \\
\hline Leaves $^{\mathrm{**}}$ & $2,952.9$ & 56 & 15 & 41 & 0.91 \\
\hline Reproductive parts ${ }^{\mathrm{G}^{* *}}$ & $3,375.0$ & 72 & 17 & 55 & 1.00 \\
\hline \multirow[t]{2}{*}{ Total $^{\mathrm{***}}$} & $6,310.8$ & 49 & 9 & 40 & 0.99 \\
\hline & \multicolumn{5}{|c|}{ Copper } \\
\hline $\operatorname{Root}^{\mathrm{G}^{* *}}$ & 195.9 & 85 & 28 & 57 & 0.99 \\
\hline Stem $^{G^{* *}}$ & 41.6 & 71 & 24 & 47 & 0.94 \\
\hline Leaves $^{* * *}$ & 56.1 & 53 & 6 & 47 & 0.95 \\
\hline Reproductive parts ${ }^{S * *}$ & 396.5 & 56 & 10 & 46 & 0.96 \\
\hline \multirow[t]{2}{*}{ Total $^{\text {*** }}$} & 717.1 & 53 & 11 & 42 & 0.99 \\
\hline & \multicolumn{5}{|c|}{ Iron } \\
\hline $\operatorname{Root}^{\mathrm{NS}}$ & - & - & - & - & - \\
\hline Stem $^{G^{* *}}$ & $1,356.9$ & 84 & 27 & 57 & 0.98 \\
\hline Leaves $^{\mathrm{G}^{* *}}$ & $1,532.1$ & 69 & 25 & 44 & 0.93 \\
\hline Reproductive parts ${ }^{S * *}$ & $4,881.3$ & 53 & 10 & 43 & 0.96 \\
\hline \multirow[t]{2}{*}{ Total $^{S * *}$} & $10,933.1$ & 46 & 11 & 35 & 0.98 \\
\hline & \multicolumn{5}{|c|}{ Manganese } \\
\hline $\operatorname{Root}^{G^{* *}}$ & 171.6 & 64 & 21 & 43 & 0.96 \\
\hline Stem $^{G^{* *}}$ & 168.2 & 80 & 26 & 54 & 0.99 \\
\hline Leaves $^{\mathrm{S**}}$ & $3,256.9$ & 73 & 16 & 57 & 0.99 \\
\hline Reproductive parts $\mathrm{G}^{\mathrm{G}^{* *}}$ & $1,550.8$ & 84 & 22 & 62 & 0.99 \\
\hline \multirow[t]{2}{*}{ Total $^{* * *}$} & $4,746.8$ & 62 & 13 & 49 & 0.99 \\
\hline & \multicolumn{5}{|c|}{ Zinc } \\
\hline $\operatorname{Root}^{\mathrm{G}^{* *}}$ & 292.4 & 92 & 38 & 54 & 0.89 \\
\hline Stem $^{G^{* *}}$ & 210.4 & 70 & 26 & 44 & 0.91 \\
\hline Leaves $^{\mathrm{NS}}$ & - & - & - & - & - \\
\hline Reproductive parts ${ }^{S * *}$ & $2,497.6$ & 67 & 15 & 52 & 0.93 \\
\hline Total $^{\text {*** }}$ & $2,854.1$ & 57 & 16 & 41 & 0.94 \\
\hline
\end{tabular}

$\mathrm{ns}=$ not significant $; \mathrm{G}=$ gaussian model: $\mathrm{a} * \exp \left\{-0.5^{*}[(\mathrm{x}-\mathrm{x} 0) / \mathrm{b}]^{2}\right\} ; \mathrm{S}=$ sigmoidal model: $\mathrm{a} /$ $\{1+\exp [-(\mathrm{x}-\mathrm{x} 0) / \mathrm{b}]\} ; \mathrm{L}=$ lorentzian model: $\mathrm{a} /\left\{1+[(\mathrm{x}-\mathrm{x} 0) / \mathrm{b}]^{2}\right\}$. beginning of the reproductive phase until the end of the cycle, the percentage of $\mathrm{B}$ accumulation in the reproductive organs varied from 30 to $60 \%$ of the total accumulated. At the end of the cycle the maximum accumulation was of $3,375.0$ $\mu \mathrm{g}$ plant ${ }^{-1}$.

For $\mathrm{Cu}$ (Figure 4B), the maximum point of total accumulation, of 717.1 $\mu$ plant $^{-1}$ (Table 2), was reached at the end of the cycle (80 DAE), because it was adjusted to the sigmoidal model. In the plant's growth phase, the leaves and roots were responsible for the highest $\mathrm{Cu}$ allocation. At the beginning of the reproductive phase, the accumulation in the leaves showed the highest reduction up until the end of the cycle, and varied from $43 \%$ to $9 \%$ of the total, whereas in the roots, even after losses, there was an average of $28 \%$ of the total at the end of the cycle. Leaves and roots showed maximum accumulation rates of 56.1 and $195.9 \mu \mathrm{g}$ plant $^{-1}$ respectively.

Regarding redistribution, in the full fruiting phase (50 DAE) more than 50\% of the copper was already allocated in the reproductive parts, after sigmoidal adjustment. The maximum point, of $396.5 \mu$ g plant $^{-1}$, occurred at the end of the cycle, and reached $57 \%$ of the total amount in the plant.

Iron, manganese and zinc accumulation

The accumulation curves for $\mathrm{Fe}$, $\mathrm{Mn}$ and $\mathrm{Zn}$ are shown in Figure 4, and their respective equation adjustments are shown in Table 2. Among the micronutrients, iron was the one accumulated in greatest quantities throughout all of the plant's development stages.

The total maximum accumulated amount of $\mathrm{Fe}, 10,933.1 \mu \mathrm{g} \mathrm{plant}^{-1}$, occurred at $80 \mathrm{DAE}$. The behavior was adjusted to the sigmoidal model (Table 2 ). As shown in Figure 4C, only the roots' rates were not mathematically adjusted, due to fluctuations over the different growth phases, with two points of excess at 40 and $80 \mathrm{DAE}$.

According to Hansch \& Mendel (2009), the Fe content in the plant that enables a satisfactory development is around 50 to $150 \mu \mathrm{g} \mathrm{g}^{-1}$, depending on the plant species. For yard long beans, the concentration estimated based on 
the accumulation rate was of $159 \mu \mathrm{g} \mathrm{g}^{-1}$ on average.

In the growing phase, the roots showed the highest allocation at 40 DAE. From this point on, the reproductive phase showed the highest allocation intensity. At the full fruiting phase (50 DAE) there is an increase in Fe accumulation, and the element's contents reach the end of the cycle with $63 \%$ of the total, or $4,881.3 \mu \mathrm{g}_{\text {plant }}{ }^{\mathbf{1}}$.

According to Kirkby \& Romheld (2007), when incorporated in chloroplasts Fe has very limited mobility inside the plants. However, it may be translocated through the phloem, mainly in the most demanding phase, the reproductive one.

For Mn (Figure 4D), the Gaussian model was the best fit, and the point of maximum total accumulation, 4,746.78 $\mu \mathrm{g}$ plant $^{-1}$, occurred at 80 DAE. The turning point was observed at $49 \mathrm{DAE}$ (Table 2).

$\mathrm{Mn}$ is intensely used in plant leaf tissues, as it takes part in essential photosynthesis processes, such as in water division in photosystem II (PSII), which supplies the electrons needed for photosynthesis (Milaleo et al., 2010).

Therefore, the leaf was expected to be the main organ of allocation for this nutrient, specially in the growth phase. The values were distributed between 54 and $73 \%$ throughout the cycle, and maximum accumulation, of 3,256.9 $\mu \mathrm{g}$ plant $^{-1}$, was reached at 80 DAE.

In the reproductive phase, the highest accumulation point, of $1,550.8 \mu \mathrm{g}$ plant $^{-1}$, was reached at 80 DAE (Figure 4D). Together with $\mathrm{Ca}$, this element's content did not surpass the leaf content in accumulation percentage during the reproductive phase (Table 2 ).

For Zn (Figure 4E), total accumulation was better adjusted to the sigmoidal model, and showed maximum allocation of 2,854.1 $\mu \mathrm{g}$ plant $^{-1}$ at the end of the cycle. It is noteworthy that the reproductive part was also adjusted to the same model, which yielded an accumulation of $2,497.6 \mu$ plant $^{-1}$, or up to $71 \%$ of the total allocation (Table 2).

$\mathrm{Zn}$ is required by plants for the regulation of functions such as transcription and translation, for the structural stability of proteins, for the regulation of oxidoreductase and hydrolytic enzymes, as well as for controlling various enzyme activities (White \& Broadley, 2011). According to Hansch \& Mendel (2009), its contents in the plant tissue should be around 15 to $50 \mu \mathrm{g} \mathrm{g}^{-1}$. In this experiment the total concentration in the tissue was $40.1 \mu \mathrm{g}$ $\mathrm{g}^{-1}$ on average.

Regarding partitioning, there was a wide variation in this element's allocation. Up to $20 \mathrm{DAE}(46 \%)$ its highest percentage was found in the roots (Figure 4). From that time onwards the leaves were the main allocation organs up until 30 DAE (54\%).

However, from 40 to $80 \mathrm{DAE}$ there was intense translocation to the reproductive structures, which are the organs accountable for the highest accumulation rates at this stage (39 to $71 \%$ ). At the end of the cycle, the roots and leaves were the organs with the highest losses, which reached up to $11 \%$ for both.

\section{Order of accumulation for nutrients}

Macronutrient and micronutrient accumulation values in yard long beans showed significant interaction at the 5\% level for total accumulation and for parts of the plants.

Taking all parts of the plants and the extraction throughout the cycle into account, the order of extraction for the macronutrients was $\mathrm{K}>\mathrm{Ca}=\mathrm{N}>\mathrm{S}=\mathrm{P}>\mathrm{Mg}$, and potassium showed the highest accumulation rate during the crop's cycle.

For the micronutrients there was little variation in the accumulation rate throughout the growth cycle, and the total extraction order at the end of the cycle was $\mathrm{Fe}>\mathrm{B}>\mathrm{Mn}>\mathrm{Zn}>\mathrm{Cu}$. Under field conditions, Fonseca et al. (2010) also detected a similar accumulation order for cowpea crops, $\mathrm{Fe}>\mathrm{B}>\mathrm{Zn}>\mathrm{Mn}>\mathrm{Cu}$, with changes only in zinc and manganese demands.

For yard long beans, the sigmoidal equation is the model that best depicted the plant's growth curve. The crop's nutritional management should be performed until 45 DAE.
The order of total nutrient extraction by the plant at the end of its cycle was $=\mathrm{N}>\mathrm{S}=\mathrm{P}>\mathrm{Mg}>\mathrm{Fe}>\mathrm{B}>\mathrm{Mn}>\mathrm{Zn}>\mathrm{Cu}$.

\section{ACKNOWLEDGMENTS}

To CAPES (Brazilian Coordination for the Improvement of Higher Education Personnel), for the financial support to the project.

\section{REFERENCES}

ALMEIDA, EIB; CORRÊA, MCM; NÓBREGA, GN; PINHEIRO, EAR; LIMA, FF. 2012. Crescimento e marcha de absorção de macronutrientes para a cultivar de melancia Crimson Sweet. RevistaAgro@mbiente 6: 205-214.

BENINCASA, MMP. 2003. Análise de crescimento de plantas: noções básicas. Jaboticabal: FUNEP, 2.ed. 42p.

BRITO, MMP; MURAOKA, T; SILVA, EC. 2009. Marcha de absorção do nitrogênio do solo do fertilizante e da fixação simbiótica em feijãocaupi (Vigna unguiculata (L.) Walp.) e feijãocomum (Phaseolus vulgaris L.) determinada com uso de ${ }^{15}$ N. Revista Brasileira de Ciência do Solo 33: 896-906.

CAIRO, PAR; OLIVEIRA, LEM; MESQUITA, AC. 2008. Análise de crescimento de plantas. Vitória da Conquista: Edições UESB. 71p.

CHATTERJEE, R; BANDYOPADHYAY, S. 2017. Effect of boron, molybdenum and biofertilizers on growth and yield of cowpea (Vigna unguiculata L. Walp.) in acid soil of eastern Himalayan region. Journal of the Saudi Society of Agricultural Sciences 16: 332-336.

FAGERIA, NK; BARBOSA FILHO, MP; STONE, LF. 2004. Nutrição de fósforo na produção de feijoeiro. In: YAMADA, T.; ABDALLA, SRS (eds). Fósforo na agricultura brasileira. Piracicaba: Associação Brasileira para Pesquisa da Potassa e Fosfato. p.435-455.

FONSECA, MR; FERNANDES, AR; SILVA, GR; BRASIL, EC. 2010. Teor e acúmulo de nutrientes por plantas de feijão caupi em função do fósforo e da saturação por bases. Revista Ciências Agrárias 53: 195-205.

HAAG, HP; MALAVOLTA, E; GARGANTINI, H; GARCIA, H. 1967. Absorção de nutrientes pela cultura do feijoeiro. Bragantia 26: 381391.

HANSCH, R; MENDEL, RR. 2009. Physiological functions of mineral micronutrients $(\mathrm{Cu}, \mathrm{Zn}$, $\mathrm{Mn}, \mathrm{Fe}, \mathrm{Ni}, \mathrm{Mo}, \mathrm{B}, \mathrm{Cl})$. Current Opinion in Plant Biology 12: 259-266.

KANO, C; CARDOSO, MO; BERNI, RF; ANTONIO, IC; SILVA, AR. 2018. Produção e nutrição do feijão-de-metro cultivado com biofertilizante. Manaus: Embrapa Amazônia Ocidental, 26p. (Boletim de Pesquisa e Desenvolvimento). 
KERTON, M; NEWBURY, HJ; MÃO, D; PRITCHARD, J. 2009. Accumulation of calcium in the centre of leaves of coriander (Coriandrum sativum L.) is due to an uncoupling of water and ion transport. Journal of Experimental Botany 60: 227-235.

KIRKBY, EA; ROMHELD, V. 2007. Micronutrientes na fisiologia de plantas: funções absorção e mobilidade. Piracicaba: Informações Agronômicas. n.118, 24p.

KUDLA, J; BATISTIC, O; HASHIMOTO, K. 2010. Calcium signals: the lead currency of plant information processing. The Plant Cell 22: 541-563.

LEAL, RM; PRADO, RM. 2008. Desordens nutricionais no feijoeiro por deficiência de macronutrientes, boro e zinco. Revista Brasileira de Ciências Agrárias 3: 301-306.

MAATHUIS, FJM. 2009. Physiological functions of mineral macronutrientes. Current Opinion in Plant Biology 12: 250-258.

MALAVOLTA, E; VITTI, GC; OLIVEIRA, SA. 1997. Avaliação do estado nutricional das plantas: principios e aplicações. 2.ed. Piracicaba: POTAFOS, 319p.

MARSCHNER, H. 2012. Mineral nutrition of higher plants. 3.ed London: Elsevier, 643p.

MILALEO, R; DIAZ, MR; IVANOV, AG; MORA, ML; ALBERDI, MAJ. 2010. Manganese as essential and toxic element for plants: transport, accumulation and resistance mechanism. Journal Soil Science Plant Nutrition 10: 476-494.

PEGORARO, RF; OLIVEIRA, D; MOREIRA, CG; KONDO, MK; PORTUGAL, AF. 2014. Partição de biomassa e absorção de nutrientes pelo feijoeiro comum. Revista Caatinga 27: 41-52.

PINHO, RG; BORGES, ID; PEREIRA, JLAR; REIS, MC. 2009. Marcha de absorção de macronutrientes e acúmulo de matéria seca em milho. Revista Brasileira de Milho e Sorgo 8: 157-173.

RAIJ, B; CANTARELLA, H; QUAGGIO, JA; FURLANI, AMC. 1996. Recomendações de adubação e calagem para o Estado de São Paulo. 2 ed. Campinas: Instituto Agronômico e Fundação IAC, 285p.

RESMI, R; GOPALAKRISHNAN, TR. 2004. Effect of plant growth regulators on the performance of yard long bean (Vigna unguiculata var. sesquipedalis (L.) Verdc.). Journal of Tropical Agriculture 42: 55-57.

SANTOS, LA; SORATTO, RP; FERNANDES, AM; GONSALES, JR. 2015. Crescimento, índices fisiológicos e produtividade de cultivares de feijoeiro sob diferentes níveis de adubação. Ceres 62: 107-115.

SÃO JOSÉ, AR; PRADO, NB; BOMFIM, MP; REBOUÇAS, TNH; ALVES e MENDES, HT. 2014. Marcha de absorção de nutrientes em anonáceas. Revista Brasileira de Fruticultura 36: $176-183$.

SILVA, FC. 2009. Manual de análises químicas de solos, plantas e fertilizantes. 2 ed. Brasília: Embrapa Informação Tecnológica, 627p.

SILVA, WG; CARVALHO, JA; OLIVEIRA, EC; REZENDE, FC; LIMA JUNIOR, JA; RIOS, GFA. 2012. Manejo de irrigação para o feijãode-metro, nas fases vegetativa e produtiva, em ambiente protegido. Revista Brasileira de Engenharia Agrícola e Ambiental 16: 978-984.

TEIXEIRA, CM; CARVALHO, GJ; SILVA, CA; ANDRADE, MJB; PEREIRA, JM. 2010. Liberação de macronutrientes das palhadas de milheto solteiro e consorciado com feijão-deporco sob cultivo de feijão. Revista Brasileira de Ciência do Solo 34: 497-505.

WHITE, PJ; BROADLEY, MR. 2011. Physiological limits to zinc biofortification of edible crops. Frontiers in Plant Science 2: 1-11.

ZOBIOLE, LHS; CASTRO, C; OLIVEIRA, FA; OLVEIRA JUNIOR, A. 2010. Marcha de absorção de macronutrientes na cultura do girassol. Revista Brasileira de Ciência do Solo 34: 425-433.

ZUCARELI, C; RAMOS JUNIOR, EU; OLIVEIRA, MA; CAVARIANI, C; NAKAGAWA, J. 2010. Índices biométricos e fisiológicos em feijoeiro sob diferentes doses de adubação fosfatada. Semina: Ciências Agrárias 31: 1313-1324. 